cessful plans of state administrative reorganization thus far adopted, such as those in Illinois, Nebraska and Idaho, have been accomplished by statutory legislation; and these might have gone further had it not been for the existing constitutional provisions. The policy followed has, therefore, been to omit from the proposed constitution all provisions relating to executive and administrative officers other than the governor.
The League's committee has also approved a constitutional provision for the merit system in the administrative service, substantially similar to the provisions in the New York and Ohio constitutions, requiring competitive examinations so far as practicable for appointments. More definite provisions as to the organization of the civil service authority and the application of the constitutional principle should be made by legislation.

\title{
THE INITIATIVE AND REFERENDUM AND THE ELECTIONS OF 1920
}

\author{
BY H, W. DODDS
}

November 2,1920 , was the occasion for submission to the people of the usual crop of constitutional amendments, referred and initiated measures. We publish herewith the votes on the various state proposals in the form of a table. The ratio of the vote on the measures to the total vote cast for all presidential electors is also given.

\section{CONSTITUTIONAL AMENDMENTS ACTED UPON}

The voters of thirty two states passed upon amendments to their state constitutions at the election last November. The proposals covered a wide variety of subjects. Eight states voted on amendments increasing the salaries of various public officers. The crest of good times had passed and the electorate had evidently begun a "buyer's strike," with respect to the services of public officials, for all salary increases were defeated. Amendments authorizing loans to pay a bonus to veterans of the late war carried in three states. Income tax provisions carried in North Carolina but failed in three other states. Special taxes or bond issues for improved roads were popular and carried in all six states which voted on them. West Virginia adopted divided sessions of the legislature while Oregon rejected a similar proposal. Absent voting authorizations carried in two states, but a compulsory voting provision failed in Oregon. Single tax amendments failed in two states, and a tax classification proposition failed in Kansas. An effort to increase the number necessary to initiate tax proposals, directed against the recurring single tax measures, failed in California. Iowa approved the calling of a constitutional convention; California defeated a similar proposal. Missouri paved the way for a convention by altering the method of electing delegates to a convention. An excess condemnation amendment failed in Michigan. New York adopted the requirement that state bonds hereafter be issued in serial form. Arkansas revised the initiative and referendum provisions of her constitution and extended them to counties and cities. The number necessary in that state to call out a measure passed by the legislature was increased from 5 to 6 per cent, and the number necessary to initiate a constitutional amendment from 8 to 10 percent. 
VOTES ON AMENDMENTS

As shown in the accompanying table the votes on the various amendments ranged from 17 per cent of the combined presidential vote in South Carolina to 32 per cent on the parochial school amendment in Michigan, and 98 per cent on a proposed trunk highway system in Minnesota. The total votes on the three proposed amendments in North Dakota were all above 90 per cent of the combined presidential votes. Partisan feeling in North Dakota, as everyone knows, was especially high at this election. With very few exceptions the votes in other states did not run as high as 80 per cent or fall as low as 40 per cent of the total vote for all presidential electors. The mean vote on all measures for all states would be about 55 per cent, which seems to be about the average for the United States in former years.

Considering the votes individually by states, the percentage of votes cast on the several amendments within each state varied but little. A spread of more than five points between the percentages of the amendments receiving the lowest and highest votes in any one state is unusual, and can generally be traced to unusual interest aroused by a certain proposal, either because of its extreme popularity or because it was more than ordinarily controversial. For the most part amendments of minor importance received as much attention as those of higher importance within the same state. It would be impossible to distinguish between measures constitutional in nature and those merely statutory by the size of the votes on them. A proposal prohibiting compulsory vaccination in California received almost one-third more votes than the proposition to call a constitutional convention. The difficulty of amending a constitution under condi- tions which require more than a simple majority of those voting on the amendment is again demonstrated. In all such cases, except three amendments in Wyoming, the proposals failed.

In six states amendments were initiated directly by the people. Such proposals, however, can hardly be said to have been distinguished by higher votes than their associates of more modest origin.

\section{THE VOTES ON INITIATED MEASURES}

Popularly initiated bills were voted upon in only eight states. One of these was Massachusetts, where an act permitting the manufacture of light beer and wines with $2 \frac{3}{4}$ per cent alcoholic content was initiated indirectly, passed both houses of the legislature, but was vetoed by the governor. On submission to the people it was approved by a close majority. Five states possessing the direct initiative did not use it at the last election. The indirect initiative was used in Massachusetts for the first time. In the other six states which employed it, however, with the exception of North Dakota, it has been of long standing (Arizona since 1911 California 1911, Colorado 1910, Montana 1906, Oklahoma 1907 and Oregon 1902). With the addition of Missouri these states comprise the group which make most common use of it. The other states which use it but rarely did not use it at all last November.

The situation in North Dakota has attracted a great deal of attention. The direct initiative was adopted in that state in 1918. Formerly, they had had only the indirect initiative. At the last election five initiated measures aimed directly at the Non-Partisan League went on the ballot. All carried by close margins. The total vote on each of them, moreover, exceeded the total vote for presidential electors, the 
former being about 110 per cent of the latter.

Other measures which received unusual attention from the voters were the alien land law in California, the law permitting the manufacture of light wines in Massachusetts and a bond issue for education in Montana. In fact, it will be seen by reference to the accompanying table that the three measures initiated in these states received an unusually high number of votes. In each case the subject of the law presented a clear issue on which popular opinion could be readily formed, and was therefore a fit matter for direct legislation.

THE VOTES ON REFERRED MEASURES

Eleven states voted on measures called out by popular petition. In contrast to the high vote in North Dakota on the initiated bills was the lower vote on a measure governing county seat removals. Prohibition enforcement acts were defeated in California and South Dakota and affirmed in Missouri and Ohio. The first three carried out the intent of the Volstead Act, but the last was designed to liberalize the prohibition law. The votes in these states were respectively 92,90 , 67 and 90 per cent of the total at the election. Other measures which attracted more than usual attention were the proposal to legalize boxing and the presidential primary repealer in Montana. Proposals to combine the direct primary and convention systems for nominating candidates were defeated in Montana and South Dakota. In each case the vote was high, being 77 and 78 per cent on the two Montana bills and 81 per cent on the South Dakota measure. However, a direct. primary repealer failed to attract the notice of the Nebraska voters for, although overwhelmingly defeated, only 38 per cent of the voters acted on it.
In this case it was the only measure on the ballot, there being no initiated bills or constitutional amendments before the people. A workman's compensation measure, defeated in Missouri, elicited little attention from the people. The votes on it were but 54 per cent of the total. In seven states there was but one referred measure on the ballot; in three states there were two measures; in one there were four measures, and in one state (California) there were five. As in the case of initiated bills those states which ordered a referendum on the most measures were the ones which have in years past utilized the privilege most frequently (i.e., Arizona, California, Missouri, Montana and South Dakota). Oklahoma and Oregon, states frequently employing the referendum in years past, voted on but one referred measure each. However, the number of times the referendum has been used in Oregon is only a fraction of the times the initiative has been invoked, which would indicate that legislative inertia was more unpopular in that state than the legislative product.

The subject matter of the referred bills was such as to enable the people to form an intelligent opinion without undue labor and, with but two or three exceptions, the size of the vote on them justified the claims made by the advocates of this form of direct legislation.

\section{THE TABLE}

In explanation of the table that follows, it may be said that the affirmative and negative votes on the measures were furnished by the secretaries of state of the several states. The votes for presidential electors were furnished by the New York Times. It is possible that the figures here given will be modified slightly in the official and final announcements of the returns in all the states. 
VOTE ON CONSTITUTIONAL AMENDMENTS, NOVEMBER 2, 1920

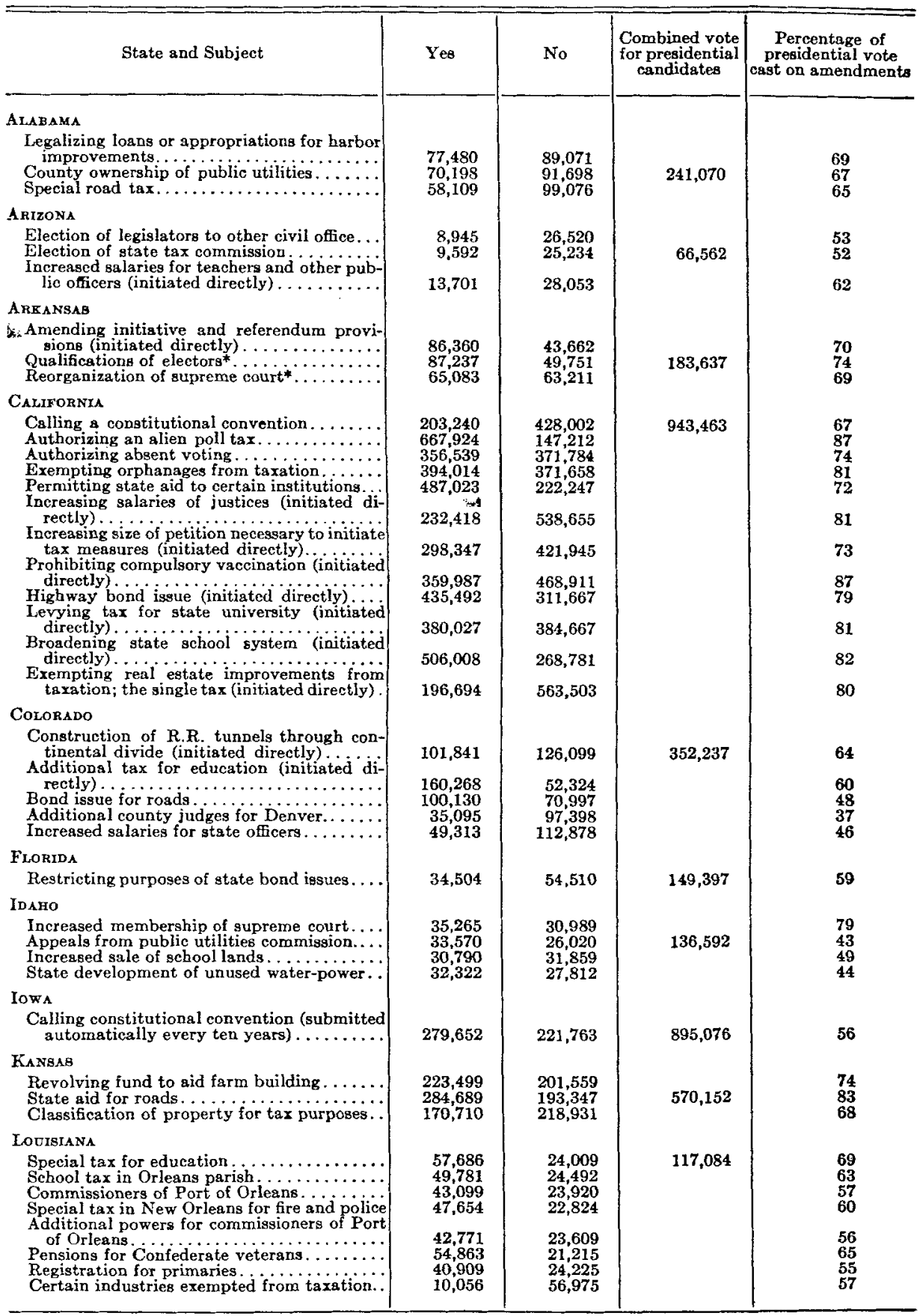

* Amendments proposed by legislature must receive affirmative vote of all voting at election. 
VOTE ON CONSTITUTIONAL AMENDMENTS, NOVEMBER 2, 1920)-(Continued)

\begin{tabular}{|c|c|c|c|c|}
\hline State and Subject & Yes & No & $\begin{array}{c}\text { Combined vote } \\
\text { for presidential } \\
\text { candidates }\end{array} \mid$ & $\begin{array}{l}\text { Percentage of } \\
\text { pregidential vote } \\
\text { cast on amendments }\end{array}$ \\
\hline $\begin{array}{l}\text { MaIve } \\
\text { Authorizing legislature to prescribe election } \\
\text { districts and manner of voting } \ldots \ldots \ldots \ldots \ldots \ldots \ldots \ldots \ldots \\
\text { Bond issue for war bonus. } \\
\text { Authorizing income tax } \ldots \ldots \ldots \ldots \ldots \ldots \ldots \ldots \ldots\end{array}$ & $\begin{array}{r}76,129 \\
105,712 \\
53,475\end{array}$ & $\begin{array}{l}29,333 \\
32,820 \\
64,787\end{array}$ & 197,845 & $\begin{array}{l}53 \\
70 \\
60\end{array}$ \\
\hline $\begin{array}{l}\text { MaRYLAND } \\
\text { Increasing salaries of members of legislature } \\
\text { Increasing salaries of clerks of courts....... }\end{array}$ & $\begin{array}{l}76,367 \\
58,081\end{array}$ & $\begin{array}{l}116,762 \\
127,638\end{array}$ & 438,451 & $\begin{array}{l}44 \\
42\end{array}$ \\
\hline 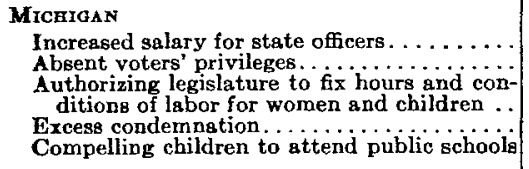 & $\begin{array}{l}348,311 \\
415,780 \\
420,085 \\
360,668 \\
353,817\end{array}$ & $\begin{array}{l}463,959 \\
359,749 \\
413,362 \\
439,373 \\
610,699\end{array}$ & $1,047,819$ & $\begin{array}{l}77 \\
74 \\
79 \\
76 \\
\mathbf{9 2}\end{array}$ \\
\hline 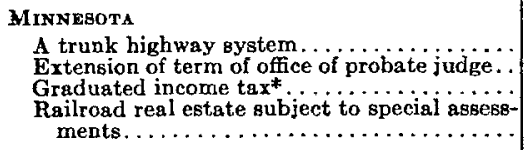 & $\begin{array}{l}526,936 \\
446,959 \\
331,105 \\
488,497\end{array}$ & $\begin{array}{r}199,603 \\
171,414 \\
217,558 \\
98,045\end{array}$ & 735,838 & $\begin{array}{l}98 \\
84 \\
74 \\
79\end{array}$ \\
\hline 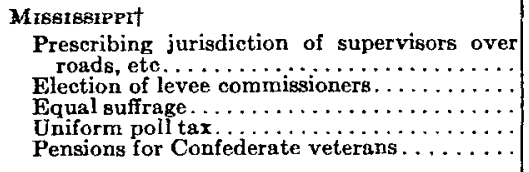 & $\begin{array}{l}20,184 \\
33,236 \\
39,186 \\
41,693 \\
42,442\end{array}$ & $\begin{array}{l}45,938 \\
26,744 \\
24,296 \\
22,733 \\
19,542\end{array}$ & 82,492 & $\begin{array}{l}80 \\
72 \\
76 \\
78 \\
75\end{array}$ \\
\hline 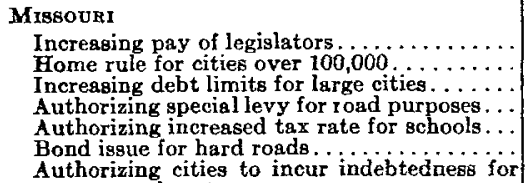 & $\begin{array}{l}320,406 \\
385,656 \\
368,651 \\
375,942 \\
312,323 \\
572,514\end{array}$ & $\begin{array}{l}406,672 \\
311,922 \\
329,938 \\
340,665 \\
398,279 \\
339,021\end{array}$ & $1,332,800$ & $\begin{array}{l}54 \\
52 \\
52 \\
53 \\
53 \\
68\end{array}$ \\
\hline 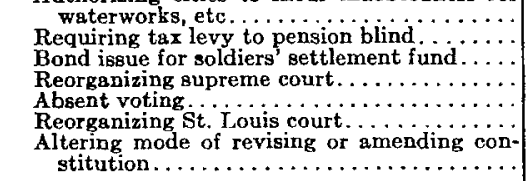 & $\begin{array}{l}381,794 \\
455,227 \\
379,156 \\
315,837 \\
440,102 \\
316,661 \\
394,437\end{array}$ & $\begin{array}{l}310,210 \\
295,788 \\
348,749 \\
369,077 \\
279,490 \\
355,401 \\
317,815\end{array}$ & & $\begin{array}{l}52 \\
56 \\
54 \\
51 \\
54 \\
50 \\
53\end{array}$ \\
\hline $\begin{array}{l}\text { MONTANA } \\
\text { Establishing county bogrds of equalization } \\
\text { under state tax commission. } \\
\text { Apportioning interest on sehool funds .......... } \\
\text { Creating board of examiners and control. }\end{array}$ & $\begin{array}{l}58,571 \\
77,093 \\
51,072\end{array}$ & $\begin{array}{l}72,161 \\
54,184 \\
72,870\end{array}$ & 179,006 & $\begin{array}{l}73 \\
73 \\
69\end{array}$ \\
\hline $\begin{array}{l}\text { NeVada } \\
\text { Jurisdiction of supreme court............. }\end{array}$ & 12,060 & 3,235 & 27,093 & 56 \\
\hline 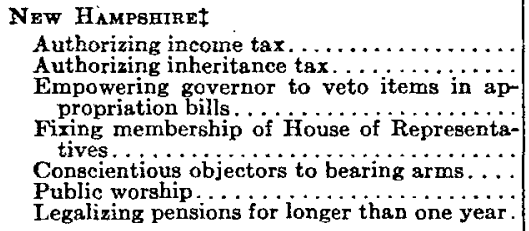 & $\begin{array}{l}46,430 \\
45,415 \\
45,634 \\
48,598 \\
35,932 \\
35,172 \\
44,456\end{array}$ & $\begin{array}{l}30,364 \\
24,222 \\
26,195 \\
28,121 \\
31,509 \\
42,322 \\
31,995\end{array}$ & 159,092 & $\begin{array}{l}48 \\
43 \\
45 \\
48 \\
42 \\
48 \\
48\end{array}$ \\
\hline $\begin{array}{l}N_{\text {Ww }} \text { York } \\
\text { Serial bonds for state debt issues.......... }\end{array}$ & $1,117,546$ & 630,265 & $2,882,590$ & 66 \\
\hline 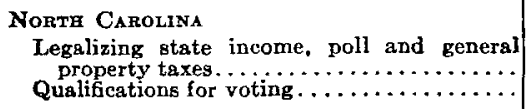 & $\begin{array}{l}262,873 \\
235,608\end{array}$ & $\begin{array}{l}81,109 \\
83,366\end{array}$ & 548,741 & $\begin{array}{l}62 \\
58\end{array}$ \\
\hline
\end{tabular}

* Lost, necessary to ratify 398,978 .

7 Necessary to carry an amendment proposed by legislature 41,559 , or majority voting at election.

$\$$ Two-thirds vote necessary to adopt amendment. All seven failed. 
VOTE ON CONSTITUTIONAL AMENDMENTS, NOVEMBER 2, 1920-(Concluded)

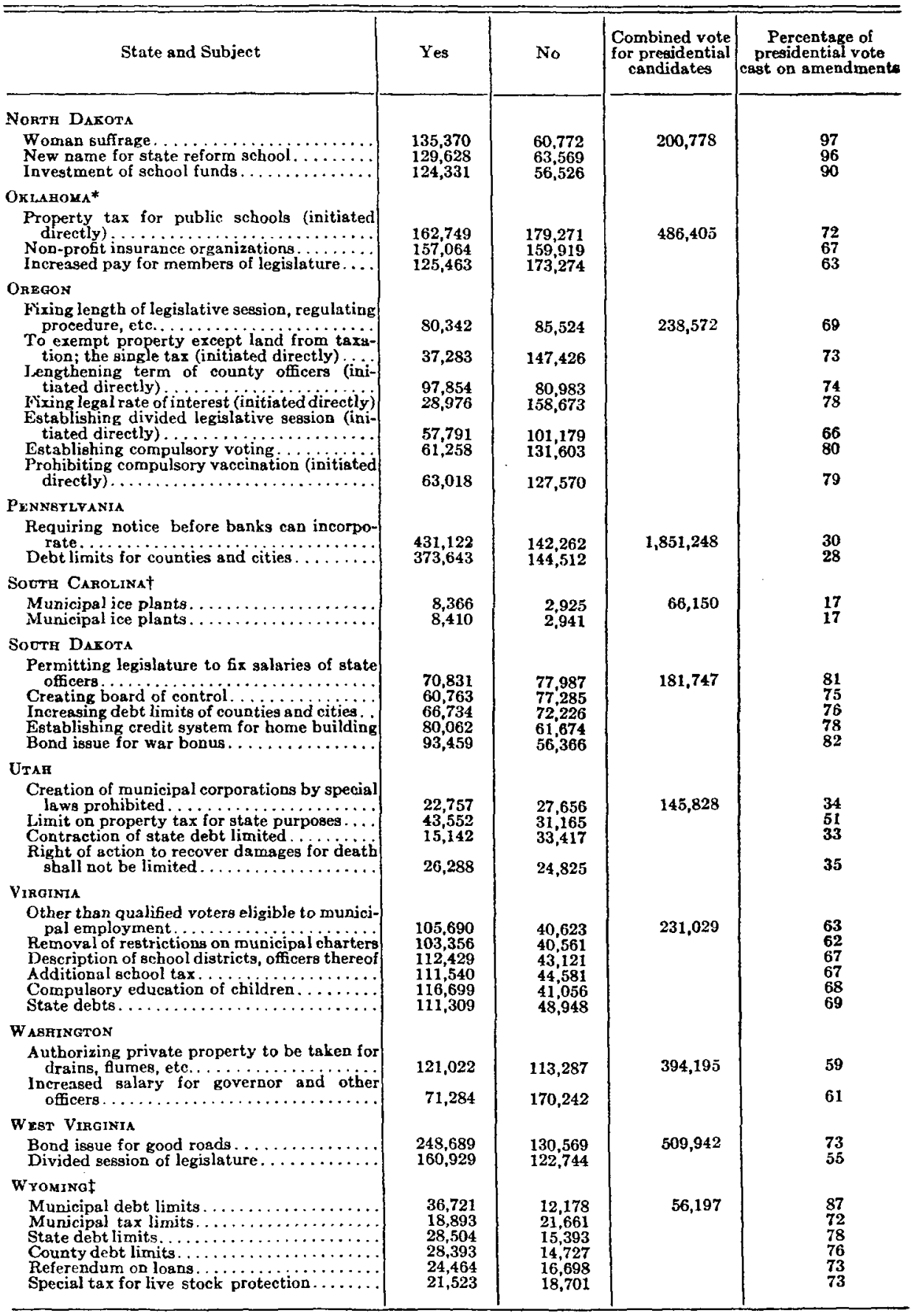

* All failed; majority of those voting at election necessary to carry amendment.

+ Thirty other amendments of local or minor nature were acted upon.

: Amendment must receive affirmative vote of all voting at election. 
VOTES ON BILLS INITIATED BY POPULAR PETITION, NOVEMBER 2, 1920

\begin{tabular}{|c|c|c|c|c|}
\hline State and Subject & Yes & No & $\begin{array}{c}\text { Combined vote } \\
\text { for presidential } \\
\text { candidateg }\end{array}$ & $\begin{array}{l}\text { Percentage of } \\
\text { presidential vote } \\
\text { cast on measure }\end{array}$ \\
\hline 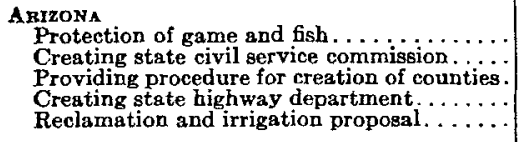 & $\begin{array}{r}13,096 \\
11,850 \\
5,312 \\
16,961 \\
18,203\end{array}$ & $\begin{array}{l}26,617 \\
26,299 \\
38,198 \\
25,721 \\
22,432\end{array}$ & 66,562 & $\begin{array}{l}59 \\
57 \\
65 \\
63 \\
61\end{array}$ \\
\hline 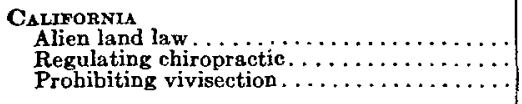 & $\begin{array}{l}668,483 \\
390,240 \\
272,288\end{array}$ & $\begin{array}{l}222,086 \\
402,410 \\
527,130\end{array}$ & 943,463 & $\begin{array}{l}94 \\
84 \\
85\end{array}$ \\
\hline 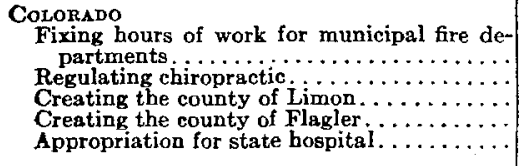 & $\begin{array}{r}113,140 \\
84,286 \\
34,881 \\
33,295 \\
155,049\end{array}$ & $\begin{array}{r}82,596 \\
109,385 \\
141,239 \\
140,363 \\
50,295\end{array}$ & 352,237 & $\begin{array}{l}55 \\
55 \\
50 \\
50 \\
58\end{array}$ \\
\hline $\begin{array}{l}\text { MaBsaCBUBETrs } \\
\text { Regulating the manufacture of beer and } \\
\text { wines (indirectly initiated) } \ldots \ldots \ldots \ldots \ldots \ldots\end{array}$ & 442,215 & 432,951 & 994,694 & 88 \\
\hline $\begin{array}{l}\text { MontaNa } \\
\text { Levying tax for state university } \ldots \ldots \ldots \ldots \\
\text { Authorizing bond issue for education. } \ldots \ldots \ldots \\
\text { Bond issue for irrigation. } \ldots \ldots \ldots \ldots \ldots \ldots\end{array}$ & $\begin{array}{l}82,669 \\
90,441 \\
55,276\end{array}$ & $\begin{array}{l}71,169 \\
66,237 \\
89,828\end{array}$ & 179,006 & $\begin{array}{l}85 \\
87 \\
81\end{array}$ \\
\hline $\begin{array}{l}\text { North Dakota } \\
\text { Eramination of bank of North Dakota, etc. }\end{array}$ & 118,269 & 102,238 & 200,778 & 110 \\
\hline $\begin{array}{l}\text { Permitting deposit of local government funds } \\
\text { in local banks... }\end{array}$ & 114,022 & 106,853 & & 110 \\
\hline $\begin{array}{l}\text { Prohibiting bank of North Dakota from lend- } \\
\text { ing on real estate to any but actual farmers } \\
\text { Permitting publication of private legal notices } \\
\text { in other papers than the official paper in }\end{array}$ & 116,508 & 105,348 & & 110 \\
\hline $\begin{array}{l}\text { the county........................................... } \\
\text { Restoring to superintendent of publie instrue- }\end{array}$ & 114,320 & 105,961 & & 109 \\
\hline tion certain powers...................... & 114,571 & 104,722 & & 109 \\
\hline $\begin{array}{l}\text { OrLAHOMA } \\
\text { Levying tax on public service corporations.. }\end{array}$ & 162,749 & 179,271 & 486,405 & 70 \\
\hline 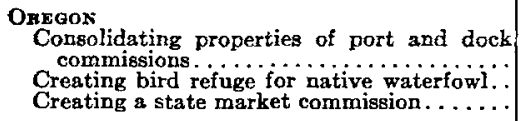 & $\begin{array}{l}80,493 \\
78,961 \\
51,605\end{array}$ & $\begin{array}{r}84,830 \\
107,383 \\
119,464\end{array}$ & 238,572 & $\begin{array}{l}70 \\
78 \\
72\end{array}$ \\
\hline
\end{tabular}


VOTES ON MEASURES REFERRED TO THE PEOPLE, NOVEMBER 2, 1920

\begin{tabular}{|c|c|c|c|c|}
\hline State and Subject & Yes & No & $\begin{array}{c}\text { Combined vote } \\
\text { for presidential } \\
\text { candidates }\end{array}$ & $\begin{array}{l}\text { Percentagejof } \\
\text { presidential vote } \\
\text { cast on measure }\end{array}$ \\
\hline 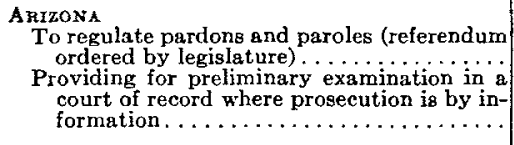 & 12,268 & $\begin{array}{l}25,794 \\
23,622\end{array}$ & 66,562 & 54 \\
\hline 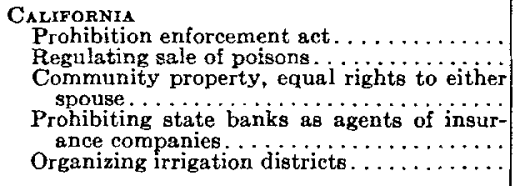 & $\begin{array}{l}400,475 \\
479,764 \\
246,875 \\
\\
308,062 \\
\mathbf{3 1 4 , 5 2 2}\end{array}$ & $\begin{array}{l}465,537 \\
270,562 \\
524,133 \\
328,115 \\
280,948\end{array}$ & $943,4(i 3$ & $\begin{array}{l}92 \\
79 \\
81 \\
67 \\
63\end{array}$ \\
\hline $\begin{array}{l}\text { IDAно } \\
\text { Bond issue for state highways (referendum } \\
\text { ordered by constitution)................ }\end{array}$ & 40,720 & 30,901 & 136,592 & 52 \\
\hline $\begin{array}{l}\text { MalNE } \\
\quad \text { Woman suffrage } \ldots \ldots \ldots \ldots \ldots \ldots \ldots\end{array}$ & 88,080 & 30,462 & 197,845 & 60 \\
\hline 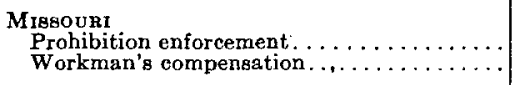 & $\begin{array}{l}\mathbf{4 8 1}, 880 \\
\mathbf{3 4 4 , 7 2 4}\end{array}$ & $\begin{array}{l}420,581 \\
376,651\end{array}$ & $1,332,800$ & $\begin{array}{l}67 \\
54\end{array}$ \\
\hline 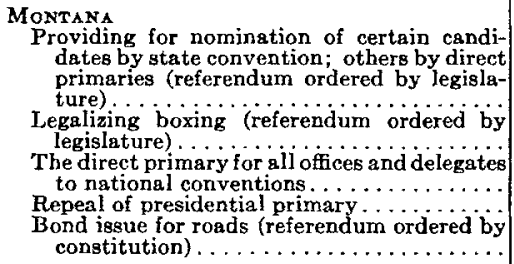 & $\begin{array}{l}60,483 \\
74,549 \\
66,131 \\
60,793 \\
68,785\end{array}$ & $\begin{array}{l}77,549 \\
82,827 \\
74,079 \\
80,023 \\
76,949\end{array}$ & 179,006 & $\begin{array}{l}77 \\
88 \\
78 \\
80 \\
81\end{array}$ \\
\hline $\begin{array}{l}\text { NEBRABKA } \\
\quad \text { Abolishing direct primary for nominations to } \\
\quad \text { certain offices } \ldots \ldots \ldots \ldots \ldots \ldots \ldots \ldots \ldots\end{array}$ & 49,410 & 133,115 & 475,153 & 38 \\
\hline 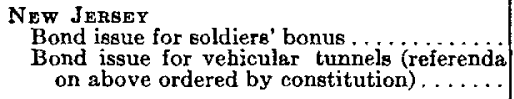 & $\begin{array}{l}534,532 \\
569,300\end{array}$ & $\begin{array}{r}165,555 \\
94,707\end{array}$ & 904,000 & $\begin{array}{l}77 \\
77\end{array}$ \\
\hline $\begin{array}{l}\text { NEw Yonk } \\
\text { Bond issue on soldier's bonus (referendum } \\
\text { ordered by constitution) } \ldots \ldots \ldots \ldots \ldots \ldots\end{array}$ & $1,454,940$ & 673,292 & $2,882,590$ & 72 \\
\hline $\begin{array}{l}\text { NoRTH DAsota } \\
\text { County seat removal... }\end{array}$ & 92,213 & 85,637 & 200,778 & 88 \\
\hline $\begin{array}{l}\text { OHIo } \\
\quad \text { Prohibition enforcement act } \ldots \ldots \ldots \ldots \ldots\end{array}$ & $1,050,045$ & 773,226 & $2,019,166$ & 90 \\
\hline $\begin{array}{l}\text { OxLAномa } \\
\text { Regulating the practice of medicine......... }\end{array}$ & 211,252 & 164,788 & 486,405 & 77 \\
\hline $\begin{array}{l}\text { OrbGoN } \\
\text { Regulating sale of oleomargarine.......... }\end{array}$ & 67,101 & 119,126 & 238,572 & 78 \\
\hline 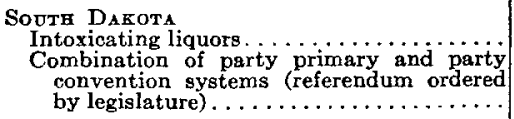 & $\begin{array}{l}75,870 \\
65,107\end{array}$ & $\begin{array}{l}87,986 \\
82,012\end{array}$ & 181,747 & 90 \\
\hline 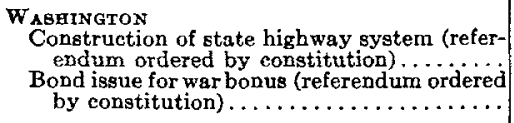 & $\begin{array}{l}117,425 \\
224,356\end{array}$ & $\begin{array}{r}191,783 \\
88,128\end{array}$ & 394,195 & $\begin{array}{l}78 \\
78\end{array}$ \\
\hline
\end{tabular}

